\title{
FINDING ECOLOGICAL VOICES AND ‘TONGUES IN TREES’ IN THE PLAY, AS YOU LIKE IT
}

\author{
DR. RAGHAVENDRA NAYAK \\ Assistant Professor and Head, Dept. of English Government, First Grade College, \\ Manvi, Raichur, Karnataka State, India
}

\begin{abstract}
This paper argues how literary environmentalism can be served as a vital method for analyzing the play As You Like It, by William Shakespeare. The play is a purely setting with rustic characters and background which draws the Forest of Arden as a setting of environmental voice and the cultural connection toward the place whereas the Forest of Arden symbolizes the fostering values. The presence and order of the tree is more than a symbol of practical design and a matter of fact. However, while the characters such as Jaques and Touchstone celebrate the concern of ecological voices and the utopian status into question, as Duke Senior who celebrate the culture of the Forest of Arden as a new world on earth. In this paper, I carefully observe how Shakespeare dramatizes the institutions of characters and also examine the performing practices and the textual meanings that is facing the utopian imagination in the Elizabethan era.

KEYWORDS: Ecological Voices and Tongues, Textual Meaning, Treatment of Nature, Ecological Sustainability \& Ecological Intrinsic and Extrinsic
\end{abstract}

Received: Jul 03, 2021; Accepted: Jul 23, 2021; Published: Aug 07, 2021; Paper Id.: IJELDEC202110

\section{INTRODUCTION}

Literary environmental imagination is an old but valid and vital integration, interpretation of the textual meaning and the performing practices in the genre of dramas. Especially in the plays of William Shakespeare, ecological voices are learned mode whereas tongues a well-performed. When turning to Shakespeare's tragedies run with treatment of love and obsession as "an incidental theme" (Dickey 105) likewise his romance plays develop treatment of love and nature as essential and basic observations. This attitude is deliberately using Shakespeare's treatment of nature as a vital resonance in the play.

Most of the existing or stock characters in the play such as Jaques, Touchstone and Rosalind are a vital voice in nature as a mature image that is intended to convey a message of tongue. Setting of the place in the play is quite loud and clear about the actions that take place in the Forest of Arden. The forest is a main focus of region of wide-ranging forest, rough topography, green hills and a widen ridges, and probably it had described as a home town of Shakespeare. The Forest of Arden is ecologically and geographically rich and finds a wide range of rocks. It may be connected and shared the location between France and England. However, the play opens with the conflicts between two brothers Duke Senior and Frederick for power and property. The younger brother Duke Frederick seized a whole property, threw his older brother out of power and exiled him. The new Duke Frederick allowed Rosalind, his brother's only daughter, to stay at court with his only child, Celia. After being tormented by his older brother, Oliver, Orlando, a young gentleman who fell in love with Rosalind at first sight, is forced to flee his house. Rosalind is expelled from the court by Duke Frederick, who is enraged. Celia and Rosalind have agreed 
to flee together, accompanied by Touchstone, the court idiot, with Rosalind posing as a young man and Celia as an impoverished lady. In the meantime, Celia speaks to Rosalind;

Peradventure this is not Fortune's work neither,

but Nature's, who perceiveth our natural wits too

dull to reason of such goddesses, and hath

sent this natural for our whetstone, for always the dullness

of the fool is the whetstone of the wits. (Act I. Scene ii.50-55)

Here it highlights in the dialogue of Celia that a witty and clever remark about the special function of Touchstone, a fool, in the nature of life. It draws the human differentiations between fortune and nature. Touchstone has sent by nature to restore orders and to bear a force of sharpen wits. Rosalind disguised as Ganymede ("Jove's own page") and Celia disguised as Aliena (Latin for "random person") ride to the Arcadian Forest of Arden, where the exiled Duke now lives with some followers, which would include "the melancholy Jaques," a dissatisfied, discontented and unhappy figure whose been introduced weeping over the butchering of a deer. Jaques often stands an outsider but who carefully observes and comments on the action. He may even acknowledge them with sharpen wits and ecological concern. He is the real voice of the play. Because his role is usually both textual meaning and performing practices which deeply rooted in the ecological concept. The concept of ecological voice is highly variable with morally and sympathy. Meanwhile, Orlando and his servant Adam track down the Duke and his troops and eventually discover themselves living with them, posting simple love poems for Rosalind on the trees in Act III Scene ii. Orlando hangs his lovely verses in admiration of Rosalind on the trees in the Forest of Arden.

Thy huntress' name that my full life doth sway.

O Rosalind! these trees shall be my books

And in their barks my thoughts I'll character;

That every eye which in this forest looks

Shall see thy virtue witness'd everywhere.

Run, run, Orlando; carve on every tree

The fair, the chaste and unexpressive she. [Act III, Scene ii, 4-10]

Orlando dedicated all his verses to his dreamy girl Rosalind. Here one think need to signal the idea of environmental imagination such as 'trees are books', 'thoughts are character', 'forest looks as a virtue that reflected or witnessed everywhere', and 'The fair, demure or chaste and unexpressive she is'. He compares his lover to the everlasting natural elements on earth. Orland who conforms and confesses his pure love verses are 'trees', his intensive emotions are 'virtue witnessed' and finally says trees are poems those are 'fair', 'chaste' and 'unexpressive' ways. Rosalind, who is also in love with Orlando, disguises herself as Ganymede and approaches him, claiming to be able to cure him of his love. Ganymede claims that "he" will stand in for Rosalind and that "he" and Orlando will be able to act out their romance. 
Phebe, Silvius's love interest, has fallen in love with Ganymede (Rosalind in disguise), despite "Ganymede's" insistence that "he" is not interested. Meanwhile, Touchstone has fallen in love with Audrey, the dull-witted shepherdess, and is attempting to court her, but is obliged to marry first. Another shepherd, William, tries to marry Audrey as well, but Touchstone stops him, threatening to murder him "a hundred and fifty ways". In this way, Touchstone, who prefers to live a simple and rural life by the side, interests in the life of the countryside rather than praising the life in the court. He compares shepherds to "bawds" (pimps that interact with prostitutes typically keep control over them while living off their earnings.) and says they earn a living by facilitating "the copulation of cattle". He mocks Orland's poems are rhyming chatty and less communicative, and compares him to a king of girls but who brings nothing to mother.

Nevertheless, by sympathizing ecological inhabitants in literature has often come between the textual meanings and the performing practices what it initially stated. It reasonably assumes especially exclusive meanings and inclusive practices in the romance play, As You Like It. The paper has also dealt in detail with ecological investigation and observation in the play. This process of analysis is concentrating and exploring the ways of ecocriticism that the connections between literary trees and trees in the physical realm will be explored, addressed, whereas other aspects will emphasise on the usage of trees as symbolic and energy storage. In the play, there will be one particular ecocritical paradigm of voicing [the environmental elements] that will be a major thought, and it may be introduced with reference to Duke Senior, in the opening of Act II, speaks of the wonders of nature. It may inspire all of us to take a walk in the woods as the days grow short, and we may enjoy the good in everything we find. With a charming twist on a theological commonplace, the Duke examines the Forest of Arden, I quote,

And this our life, exempt from public haunt,

Finds tongues in trees, books in the running brooks,

Sermons in stones, and good in everything.

Act II, Scene I (14-16)

The very act of putting a sentence together that shows just how far we dwell from/in the source of the physical world. However, Shakespeare's language evokes a longing for our true home, which is nature. The idea- "good in everything"-captivated us that nature is our true home. That we're all longing to return home. The above-mentioned lines, delivered by the Duke Senior upon his arrival in Act II, scene I, set the play's pastoral tone. With great ideas of economy and ecology, The Forest of Arden, as depicted by Shakespeare, is both safe and healing (II.i.3). The woods are exalted and dramatized, as they are in much pastoral writing, and the tone for the rest of the play is set. Perils may appear, but they remain in the distance, and, in the end, there is "good in everything." (II.i.17). This scene, more than any other in the play, exemplifies the pastoral mode's conceits. The corruptions of court life are left behind in order to learn the country's basic and essential lessons. Shakespeare uses terminology that recalls the classroom, the library, and the church to emphasise the informative, enriching, and enlightening aspect of this venture into the woods: The Duke finds tongues, books, and sermons in the trees, brooks, and stones surrounding him. Shakespeare, therefore, goes on to alter the literary norms on which he relies while writing. His shepherds and shepherdesses, for example, eventually show too lovesick or dim-witted to impart the type of knowledge that the pastoral form needs, but for now, he just sets up the conflict between city and country that drives his drama ahead. It also evokes an intense consciousness towards the physical sources. In this scene, "tongues in trees, books in...brooks", "sermons in stones" all do their part in presumably the Duke what he is. These 
words, on the other hand, appear to be the start of a humorous challenge of the conventional notion of a natural history book. Characters "read" the Forest of Arden in fundamentally different ways, as I argue: The Duke sees virtue, Jacques sees evil, Touchstone sees both, and Corin neither. And Orlando deifies Rosalind by perverting the natural history book. All who comment on the setting, like Orlando, appear to impose their own text on the holy text of the forest. The Woodland of Arden represents a forest of freedom and transformation, whilst Nature as book was a popular image in the 1600 s.

\section{The Role of Trees in the Play}

The main intention is to argue that the forest as the actual place of healing and the trees play a bigger role in As You Like It play. In the play, the usage of forest and trees are metaphors but their positions in the plays may also indicate something about how Shakespeare's material world's especially trees and forests influenced on him. The Forest of Arden is a particularly fine example of a play that transports characters, performers, and spectators to a forest. It may possibly have been the first play to be played at the new Globe Theatre in 1599, with John Powell Ward speculating in his Harvester New Critical Introduction to the play that it was "composed probably for the opening of the Globe Theatre itself" (Ward xviii). The play As You Like It, according to ecocritic, Gabriel Egan, is more of an animal drama than a forest play. He continued that 'The likening of humankind to animals runs throughout the play' (Egan 103). It is very clear that trees occupied a vital role in the play which caused to explore humanity in the forest. According to Thomas Lodge's Rosalynde, characters are deeply connected and associated with the trees in the play. Lodge says;

Ganymede, as soon as they were out of sight, led his flocks down to a vale, and there under the shade of a beech tree sate down, and began to mourn the misfortunes of her sweetheart. And Aliena, as a woman passing discontent, severing herself from her Ganymede, sitting under a lemon tree, began to sigh out the passions of her new love, and to meditate with herself in this manner. (Lodge 105)

This metaphor conveys how to bear strange person and place, and moral lessons through learning manner and attitude in the Forest of Arden. In the play, Orlando carves merely Rosalind's name on the trees, but Rosader "engraves with his knife" a 16-line sonnet "in the bark of a myrtle tree." (78) As for Montanus, he engraved a 20-line poem "in the bark of a pine tree" (53) and 24-line one "upon the bark of the tall beech tree" (54) in Thomas Lodge's narrative. Yet Jaques asks Orlando to "mark no more trees with writing love-songs in their barks" (Act III, Scene iii, 219) which implies that Orlando and Montanus do the same thing: they turn trees into books one can read. Yet it looks as if carving long poems in tree trunks was no longer "for the fashion of those times," (Act II, Scene iii.59). As a matter of fact, Jaques the Elizabethan environmentalist, who really insists that no one should wound trees - or kill venison. His words echo those spoken by the Duke Senior who "Finds tongues in trees, books in the running". My first observation is that The Forest of Arden is the play's "primary topic," and animal analogies coexist with a small stream of man-as-plant imagery. There are numerous allusions to tree, forest, forester, oak, acorn, holly, or some other woody thing, and there is little question that trees are the backdrop. For instance, the most evident is Rosalind's "Well, this is the Forest of Arden" (Act II. Scene iv.13), but Charles the wrestler has previously called the forest where the "old Duke" currently resides: "They say he is already in the Forest of Arden, and a great many merry fellows with him" (Act I. Scene i.109-10). Celia has also stated her intentions following Rosalind's exile by the "new Duke": "to seek my uncle in the Forest of Arden" (Act I. Scene iii.104). The play does begin with debates between Nature and Fortune, and Nature and Nurture. This also blending of classical and folk myths even has a Christian echo, with the forest of Arden close enough to Eden. Such a world will not sustain murder. 
Orlando can survive bad nurturing by his fortunate brother because he is sustained by "the spirit of Arden". However, the forest setting in the play is, of course, the similarly titled site in Shakespeare's primary "timber-tree" for the play, Thomas Lodge's Rosalynde, is largely regarded as an inspiration (1590). In Act II, scene i, Jaques's lamentation on the wounded deer, and Act IV, scenei ii, which dramatizes the ecological concern and presence toward the natural lives. Jaques deeply mourned about the slaughter of animals in the play. He really stands as the Elizabethan environmentalist in the play. His speeches and inner concern clearly moralizes upon the pastoral attitudes.

Second observation is that Shakespeare's He considered the playhouse to be a metaphor for the world, just as he taken into consideration the play to be a metaphor for life. It is most notably articulated in Jaques' speech, which starts with '[a]ll the world's a stage | And all the men and women merely players' (Act II. Scene vii.140-41), and in the Duke Senior's reference to '[t]his wide and universal theatre' (Act II. Scene vii.138). The notion underlying Jaques' statement is the Forest of Arden's fate and future. In this speech, Jacques uses a well-known theatrical metaphor of seven phases of human life: I. BABY or Infant, II. SCHOOL-BOY or child, III. LOVER, IV. SOLDIER, V. JUSTICE, VI. PANTALOON (OLD MAN), VII. EXTREMLY OLD MAN (SECOND CHILD). He compares the world [of Arden] to a stage whereas all men and women are simply performers on this world [or the theatre of Arden]. The Forest of Arden symbolizes not just a theatre of world and a reference of place but it's a timeless world, a central image/symbol and a 'golden world' on earth. It's a harmonious place of cultural connection as well as communicative network between the worlds. Rosalind's gentle gestures appeared to expand upon that concept, implying that the entire universe is an ever natural vegetation. Another important notes are the oak tree that is indeed a remarkable tree contains as an imagery of being symbolic rather than idealistic. The oak tree stands as the emblem of the great age and the dignity of great old age. In observation of Adam and Corin characters eventually exposed and traditionally associated with the divinity and the mysterious spirit. The oak tree is the sacred spirit and life of human existence on earth. However, the Forest of Arden has become the moment of a primitive place. Third observation, in a central scene in the play, Orlando is exploring the forest, hanging love poetry on trees and carving his love for Rosalind into their bark, attempting to make trees communicate such as 'Hang there my poetry, in evidence of my affection,' he stated in his opening line in Act. III. Scene ii, and says that 'These trees, Rosalind, shall be my books' (Act. III. Scene. ii.). After that, he threw the rest of his papers into the crowd as if they were flyers, before concluding,

[a]nd in their barks my thoughts I'll character,

That every eye that glances in this woodland

Shall see thy goodness testified everywhere"

(Act III. Scene ii.7-8).

Orlando, enraged by love, rushes across the Arden Forest. He puts poetry in Rosalind's remembrance on every tree in the hope that pedestrians will see her "virtue witnessed everywhere" (Act. III. Scene ii.8). Later Rosalind enters, she reads one of Orlando's verse in which she is compared to a valuable diamond. It means trees are compared to the priceless jewel that causes to breath every living being on earth. It's an act of moral regeneration which signs in the forest of Arden as the garden of Eden in the Bible. Jaques stands a well moral and more concern about the natural lives in the play. Despite the widespread opinioned about Shakespeare's As You Like It, are especially secular in meaning and symbolic system especially a Christian imagery and a Classical mode depiction emphasized. 


\section{CONCLUSIONS}

As I argued that trees are enigmatic creatures that take their vitality from both the depths of the physical ground and the light of the distant sun. Exactly as we do. This has been mirrored in my approach, in which I've treated literary trees as both metaphors and images of trees in the real world. On a symbolic and literal level, I've also explored the relationship between trees and literature. Overall, the study of trees in literature is essential because trees and literature produce energy pathways to the human beings that's what having a unique relationship and been signaled a place of rejuvenate zeal, rejects lowliness in the play As You Like It. The play grounded with its integrity, its intermediateness, and its human condition in the various terms of vital connectivity in the environment.

\section{REFERENCES}

1. Clark, Albert E. Shakespeare's treatment of love: the mature. Verginia: Library University of Richmand, May 1974. http://scholarship.richmond.edu/masters-theses.

2. Dickey, Franklin M. Not Widely But Too: Shakespeare's Love Tragedies. San Marino: Huntington Library, 1957.

3. Farrar, Ryan. "As You Like It: The Thin Line Between the Legitimate Utopia and Compensatory Vacation." Utopian Studies Vol. 25, No. 2. (2014): 359-383. https://doi.org/10.5325/utopianstudies.25.2.0359.

4. Fortin, René E. "Tongues in Trees": Symbolic Patterns in As You Like It." Texas Studies in Literature and Language, Vol. 14, No. 4 (Winter 1973) (1973): 569-582. http://www.jstor.org/stable/40754228.

5. Grossman, Joanna Rebecah. Shakespeare Grounded: Ecocritical Approaches to Shakespearean Drama. Cambridge: Harvard University, 2014. http://nrs.harvard.edu/urn-3:HUL.InstRepos:13064927.

6. Lodge, Thomas. Rosalynde. Amazon: The Perfect Library,, 2010.

7. Shakespeare, William. As You Like It. Cambridge: Cambridge University Press, 2016.

8. Weimann, Robert. "Thresholds to Memory and Commodity in Shakespeare's Endings." Representations, No. 53 (Winter, 1996) (1996): 1-20.

9. Naidu, A. Lakshumu, and A. K. Duppala. "A study on different chemical treatments for natural fiber reinforced composites." Internat. J. Mechan. Product. Eng. Res. Develop 8.5: 143-152.

10. Giri, Pankaj, V. Charan Kumar, and A. Muniappan. "Investigation of Mechanical Properties of Natural Fiber Composite with \& without Fiber Surface Treatments." International Journal of Mechanical and Production Engineering Research and Development 8.4: 785-790.

11. AB Kadir, Muhammad Ismail, Mohd Rozi Ahmad, and Asmida Ismail. "The Effect of Cationic Surfactant Treatment on the Dyeability of Cotton and Silk Fabrics with Natural Dye From Brown Seaweeds Sargassum Sp." International Journal of Applied and Natural Sciences (IJANS) 5: 19-28.

12. Baranwal, Amrita, Neelma Kunwar, and Devi Sarita. "Control and Prevention of Female Infertility through Natural Herbs, Medicines and Yoga: A Review." International Journal of General Medicine and Pharmacy (IJGMP) 5: 1-6. 